\title{
HAKEKAT HUKUM PENGUPAHAN DALAM UPAYA MEWUJUDKAN KESEJAHTERAAN SOSIAL PEKERJA
}

\author{
H. Zulkarnain Ibrahim \\ Fakultas Hukum Universitas Sriwijaya \\ J1. Raya Palembang-Prabumulih Km.32 Inderalaya \\ email: zulibrahim007@gmail.com
}

\begin{abstract}
The values of Pancasila are reflected in legal idea that showed in moral standards. The legal idea is a pattern of thought that contains sublime rules, leads the remuneration law's direction and goal to create a prosperous life for society workers. The essence of Pancasila, law of idea, and moral become benchmark for government, enterpreneurs, and workers to execute the harmonious of Pancasila's Industrial Relationship system in legal certainty, justice, and expedience.
\end{abstract}

Keywords : Pancasila, Labour, Pay.

\begin{abstract}
Abstrak
Nilai-nilai Pancasila, tercermin pada cita hukum yang nampak pada standar moral. Cita hukum tersebut merupakan suatu pola pikir yang mengandung kaedah-kaedah luhur menentukan arah dan tujuan hukum pengupahan dalam rangka mewujudkan masyarakat pekerja yang hidup sejahtera. Hakekat Pancasila, cita hukum, dan moral tersebut, menjadi tolak ukur dari pemerintah, pengusaha dan pekerja dalam melaksanakan sistem Hubungan Industrial Pancasila (HIP) yang harmonis dalam kepastian hukum, keadilan dan kehasilgunaan.
\end{abstract}

Kata Kunci: Pancasila, Buruh, Upah.

\section{A. Pendahuluan}

Hukum Pengupahan yang ideal, harus berisikan nilai-nilai Pancasila untuk mencapai keadilan yang sesungguhnya baik bagi pengusaha maupun bagi masyaraakat pekerja. Dalam Upaya Mewujudkan Kesejahteraan Sosial Pekerja Sistem hubungan industrial Indonesia, adalah sistem Hubungan Industrial Pancasila (HIP). Sebab semua perundangundang nasional termasuk perundangundangan ketenagakerjaan, pada umumnya memuat: 1) awal kata dari UUK adalah "Dengan Rahmat Tuhan Yang Maha Esa; 2) konsideran mengingatnya berdasarkan: Pancasila dan UUD NRI Tahun 1945; 3) UUK Pasal 2 Pembangunan ketenagakerjaan berlandaskan Pancasila dan Undang Undang Dasar Negara Republik Indonesia Tahun 1945.

Meskipun sekarang hukum pengupahan modern telah menjadi bagian dari kebijakan perusahaan-perusahaan swasta nasional, asing dan BUMN; namun aspek filosofis semua perusahaan itu berlandaskan nilai-nilai
Pancasila. Eporia reformasi pasca pemerintahan Orde Baru, telah menimbulkan dampak negatif terhadap semangat menghargai Pancasila. Sehingga dalam UUK, rumusan yang ada adalah "Hubungan Industrial Indonesia" bukan "Hubungan Industrial Pancasila". Padahal sudah ada pemahaman tentang Hubungan Industrial Pancasila (HIP), dalam norma-norma kerja pada masa sebelum reformasi. Maka Pancasila harus dikembalikan pada paradigma yang dibangunkan oleh para Pendiri Republik Indonesia, termasuk Pancasila sebagai Cita Hukum Pengupahan.

Cita-hukum menurut B. Arief B. Sidharta, adalah gagasan, karsa, cipta, dan pikiran berkenaan dengan hukum atau persepsi tentang makna hukum, yang dalam intinya terdiri atas tiga unsur, yaitu keadilan, kehasilgunaan, dan kepastian hukum. Citahukum itu terbentuk dalam pikiran dan sanubari manusia sebagai produk berpadunya pandangan hidup, keyakinan keagamaan, dan kenyataan kemasyarakatan yang 
diproyeksikan pada proses pengkaidahan perilaku warga masyarakat yang rnewujudkan tiga unsur cita-hukum tersebut tadi. Ilmu Hukum yang mempelajari tatanan hukum sebagai sarana intelektual untuk memahami dan menyelenggarakan tatanan hukum tersebut, dalam pengembanannya seyogianya pula bertumpu dan mengacu pada cita hukum itu. ${ }^{1}$

Berbagai pendapat lain tentang cita hukum, pertama, menurut Oka Mahendra bahwa istilah rechtsidee lebih tepat diartikan cita-cita hukum. Cita-cita hukum berarti suatu pola pikir yang mengandung nilai-nilai luhur yang memberikan arah dan tujuan kepada hukum dalam rangka mewujudkan masyarakat yang dicita-citakan; kedua, A. Hamid S. Attamimi, mengutip pendapat van Eikema Hommes menyatakan bahwa meski merupakan titik akhir yang tidak mungkin dicapai, namun cita hukum memberikan manfaat karena mengandung dua sisi dengan cita hukum, hukum positif yang berlaku dapat diuji, dan kepada cita hukum, hukum positif sebagai usaha menuju sesuatu yang adil dengan sanksi pemaksa dapat diarahkan. ${ }^{2}$

Berbagai pengertian tentang cita hukum di atas, maka hakekat dari cita hukum adalah gagasan, karsa, cipta, dan pikiran hukum yang mengandung nilai-nilai luhur yang memberikan arah dan tujuan kepada hukum nasional (juga hukum pengupahan) dalam rangka mewujudkan masyarakat yang hidup menikmati kesejahteraan dan hidup terhormat dan bermartabat.

\section{B. Pembahasan \\ 1. Hakekat Substansi Pancasila sebagai Cita Hukum Pengupahan}

Tujuan cita hukum menurut Rudolf Stammler dalam bukunya Theory of Justice:
1) hukum yang benar adalah titik universal tertinggi dalam setiap studi tentang kehidupan sosial manusia; 2) hukum yang benar adalah satu-satunya yang memungkinkan pemahaman keberadaan masyarakat sebagai satu kesatuan melalui metode yang sah secara mutlak; dan 3) hukum yang benar menunjukkan jalan menuju persatuan dengan semua usaha dengan ciri fundamental yang bertujuan pada kesadaran yang benar. ${ }^{3}$ Cita hukum juga dikemukakan Rudolf Stammler, bahwa cita hukum adalah kerangka berpikir yang merupakan keharusan untuk mengarahkan hukum kepada cita-cita yang diinginkan masyarakat.

Kritikan Francois Geny terhadap teori Stammler yang tidak membatasi hukum untuk mengatur masalah yang berubah. Pertama, dari problema yang dihadapi oleh tiap ahli hukum perdata modern, yang menyadari bertambah banyaknya kekuatankekuatan sosial dan pertentanganpertentangan sosial dalam hal mana hukum tidak dapat bersikap menunggu. Geny menerapkan pada hukum klasik perbedaan: a) antara pikiran dan kemauan, dan b) antara pengetahuan dan perbuatan. Keduanya masing-masing mempunyai dua bidang: 1 . ilmu pengetahuan. Bidang ilmu pengetahuan ialah pengetahuan objektif mengenai realitasrealitas sosial yang memberi pada hukum bahan-bahan sosial. Begitu bahan ini diberikan, ahli hukum tidak dapat mengubahnya. Ahli hukum menerapkan tekniknya pada bahan ini, keterampilan dari ahli hukum yang khas, dan 2. teknik. Teknik inilah yang bagi ahli hukum merupakan bidang perbuatan yang kreatif perbedaan ini adalah dari ajaran Kant, sepanjang menerapkan perbedaan yang esensial antara pikiran murni dan pikiran praktis, antara

1. B Arief Sidharta, 2011, Sebuah Gagasan tentang Paradigma Ilmu Hukum Indonesia; dalam: Elly Erawaty dkk, Beberapa Pemikiran Tentang Pembangunan Sistem Hukum Naional Indonesia, Bandung, Citra Aditya Bakti, hlm. 201-202.

2. Joni Emirzon, 2007, Hukum Usaha Jasa Penilai dari Perspektif Good Corporate Governance, Disertasi Universitas Diponogoro, Semarang, hlm.584-585.

3. Pemikiran Kant dipergunakan Stammler dalam filsafat hukumnya untuk membedakan antara:1) hukum dalam wujudnya sebagai kehendak pada satu pihak, bagi Stammler ditempatkan dalam lingkungan luar alam pikiran murni. Hukum sebagai kehendak mengadung suatu objek di dalam dirinya yang berada di luar kehendak itu sendiri. Objek tersebut berada diluarnya dan terletak di dalam alam waktu yang masih akan datang. Objek itu adalah yang menjadi tujuan dan yang oleh Stammler disebut sebagai Rechtsidee.dan 2) hukum dalam wujudnya sebagai tujuan dilain pihak. Oleh Stammler menempatkannya dalam kerangka filsafat Kant pada alam pikiran praktis. Dengan demikian menurut filsafat Stammler, alam hukum dibedakan antara konsep hukum dan ide hukum atau Rechtsidee. Pemikiran Rudolf Stammler ini, dalam kerangka pikir yang bersifat universal yang secara khusus tentulah ada bedanya cita hukum pada tiap-tiap Negara.W. Friedmann, 1990, Legal Theory,Stevens \& Sons Limited, London, 1960; Terjemahan: Muhammad Arifin, Teori dan Filsafat Hukum, Idelaisme Filosofis dan Problema Keadilan (Susunan II), Jakarta: Rajawali, hlm. 29-30. 
pikiran dan kemauan.

$K e d u a, \quad \mathrm{Francois} G \mathrm{Ge} \mathrm{y}$ mengembangkan teorinya mengenai hukum alam dalam kerangka masalah sosial ini yang memberikan bahan untuk perbuatan hukum. Menurut Geny hukum alam terdiri dari faktorfaktor yang tak berubah dan umum sifatnya yang perlu bagi bekerjanya hukum. Jadi faktor-faktor tersebut adalah dasar dari tiap hukum positif. $^{4}$

Kesenjangan hukum positip, akan terjadi kalau hukum tidak mampu memenuhi kebutuhan (tuntutan) akibat perubahan sosial tersebut. Hukum ketinggalan dari perubahan masyarakat. Menurut Yehezkel Dror, kesenjangan semacam ini tidaklah terlalu sulit diatasi dengan menggunakan tangan para hakim. Melalui penafsiran dan penemuan hukum pada umumnya, hakim berwenang mengadakan penyesuaian hukum yang ada untuk menunjang perubahan masyarakat. Namun, dapat juga terjadi sebaliknya. Hakim menjadi salah satu penghambat penyesuaian hukum dengan penubahan yang sedang terjadi. Hakim menentang sebagai peraturan baru untuk menyesuaikan atau hasilkan perubahan. Seandainya diadakan perubahan hukum, belum tentu dapat mengatasi kesenjangan. Pada negara- negara yang menjalankan hak menguji, hal semacam itu sangat mungkin terjadi. Menghadapi krisis ekonomi tahun 1929 dan seterusnya, Presiden Roosevelt membuat kebijakan yang disebut "New Deal". Berbagai undang-undang yang ditetapkan Congress serta peraturan dan kebijakan yang dikeluarkan pemerintah, seperti peraturan mengenai jam kerja, upah, perdagangan antar negara bagian dan pembatasan produksi, dibatalkan Mahkamah Agung dengan alasan bertentangan dengan UUD NRI Tahun 1945 (seperti alasan bertentangan dengan asas kebebasan berkontrak, kebebasan berniaga antar negara bagian). ${ }^{5}$

Sedangkan di Indonesia, hukum pengupahan berasaskan kebebasan melakukan perjanjian (berkontrak), telah disingkirkan oleh berbagai bentuk perjanjian baku (standar) dengan maksud untuk menghilangkan kesenjangan dalam perjanjian untuk melindungi pihak-pihak yang lemah dalam proses tawar-menawar antara kedua belah pihak. Perjanjian baku tersebut, adalah benar jika berdasarkan perundang-undangan nasional. Hubungan perburuhan dalam konteks Perjanjian kerja, peraturan perusahaan dan Perjanjian Kerja Bersama antara pekerja dengan pihak pengusaha telah dipayungi oleh undang-undang ketenagakerjaan. Penegakan hukum oleh pemerintah, di satu pihak. Kemudian di pihak lain dituntut adalah kepatuhan dan kesadaran hukum pengusaha dan pekerja. Di samping itu, antinomi antara politik dengan hukum harus berjalan dengan harmonis, sehingga politik hukum sebagai sarana untuk mewujudkan tujuan hukum.

Defenisi politik hukum sebagai legal policy atau kebijakan hukum yang diterapkan atau dilaksanakan secara nasional oleh suatu pemerintahan negara tertentu meliputi: 1) pelaksanaan secara konsisten ketentuan hukum yang telah ada; 2) pembangunan hukum yang berintikan pembaharuan atas hukum yag telah ada dan pembuatan hukumhukum baru; 3) penegakan fungsi lembaga penegakan hukum serta pembinaan para anggotanya, dan 4) peningkatan kesadaran hukum masyarakat menurut persepsi elit pengambi kebijakan. ${ }^{6}$ Kesadaran hukum masyarakat harus dimulai dari pejabat publik yang menjalankan fungsi administrasinya

4.Geny membaginya dalam empat kategori, yang ia sebut donns : (1) Le donne reel. Ini terdiri dari realitas-realitas fisik dan psikologis, seperti fakta-fakta dibidang seks atau iklim, tradisi-tradisi keagamaan, perilaku sosial masyarakat; (2) Le donne historique. Ini terdiri dari fakta-fakta, tradisi, keadaan-keadaan lingkungan yang membentuk fakta-fakta fisik atau psikologis dengan cara yang khusus; (3) Le donne rationnel. Ini terdiri dari prinsip-prinsip yang bersumber pada pertimbangan-pertimbangan yang masuk akal mengenai hubungan-hubungan manusia. Ini merupakan perwujudan dari sebagian besar prinsip-prinsip hukum alam klasik, dalil-dalil pokok keadilan, seperti kesucian hidup manusia, perkembangan kecakapan-kecakapan manusia dan lebih khusus, seperti kepercayaan liberal yang kuat, seperti kebebasan berfikir dan keamanan pribadi; dan (4) Le donne ideal. Ini memberi unsur dinamis, berupa aspirasi-aspirasi moral dari masa dan peradaban tertentu. Suatu hasil dari intuisi yang lebih baik dari hasil yang diperoleh dengan akal, sebab Geny membenarkan bahwa sebagian besar dari data sosial utama yang empat ini menutupi sebagian besar bidang teknik. Lihat: W. Friedmann, Ibid., hlm. 133-134.

5.Bagir Manan, 2011, Kembali Ke Politik Pembangunan Hukum Nasional; Dalam: Elly Erawaty dkk, Beberapa Pemikiran Tentang Pembangunan Sistem Hukum Naional Indonesia, Bandung, Citra Aditya Bakti, hlm. 111-112.

6.Moh. Mahfud MD, 2010, Membangun Politik Hukum, Menegakkan Konstitusi, Jakarta, Rajawali Pers, hlm 15. 
secara tepat dan adil. Menurut Jeremy Pope, rumusan prinsip-prinsip administrasi yang baik dapat dibaca dalam Konstitusi Malawi 1994.?

Di bidang ketenagakerjaan, asas-asas pemerintahan yang baik, pertama, layanan penempatan kerja umum membantu secara serentak antara penawar kerja dengan pencari kerja. Tujuannya adalah untuk memproduksi secara besar-besaran pekerjaan berkualitas tinggi yang memenuhi persyaratan bagi kedua belah pihak dan untuk membantu "underdog dalam bursa kerja" dengan menanggung "biaya pemasangan", atau biaya pencarian kerja dari kedua belah pihak. Penetapan tunjangan pengangguran merupakan kebijakan pasif di bursa tenaga kerja. Sedangkan layanan penempatan kerja umum merupakan kebijakan yang aktif, karena pemerintah secara aktif terlibat dalam bursa tenaga kerja. ${ }^{8}$

Kedua, pada pergantian tahun 2012/2013, keteladanan Gubernur/Wakil Guburnur DKI Jakarta dengan keputusan sepihak, telah berani menetapkan UMP di wilayahnya sebesar Rp. 2.200.000,-. UMP DKI Jakarta sebelumnya berkisar Rp. 1.500.000,-. Bagi kalangan pengusaha, ditanggapi: 1) akan menggugat ke PTUN; dan 2) akan mem-PHK pekerjanya. Pihak Gubernur dalam hal ini, mempersilahkan pengusaha untuk menggugat ke PTUN tetapi gugatan tersebut tidak jadi dilaksanakan. Sikap pengusaha sekarang adalah mengajukan penundaan kenaikan UMP ke Dinas Ketenagakerjaan DKI Jakarta.

Tindakan sepihak dari Gubernur DKI, sebaiknya diterima dengan baik oleh pengusaha, sebab selama ini sangat jarang ada "inisiatif" yang datang dari pengusaha untuk menaikkan UMP yang cukup tinggi. Sebelumnya kenaikan UMP, berkisar Rp. 300.000,- Menurut G. Kartasapoetra dkk, pengusaha dan pekerja pada dasarnya adalah mitra dalam perjuangan memikul tanggungjawab, sebagai berikut: 1) terhadap Tuhan YME; 2) terhadap bangsa dan negara; 3) terhadap lingkungan masyarakat; 4) terhadap keluarga; dan 5) terhadap keduanya sendiri. ${ }^{9}$

Tanggungjawab tersebut di atas jika direnungkan dan dapat dilaksanakan oleh kedua belah pihak, harmonisasi di bidang hukum pengupahan terlaksana dengan sendirinya. Tanggungjawab pekerja dan pengusaha dalam hubungan kerja tersebut, nantinya akan menghasilkan hal-hal positif terutama kelanggengan berusaha dan bekerja.

Untuk mencari norma Pancasila menurut Sunoto, terlebih dahulu kita cari apakah hakekat sila-sila Pancasila. Intinya adalah Ketuhanan, kemanusiaan, persatuan, kerakyatan dan keadilan. Kemudian dari katakata tersebut masih dapat kita temukan lagi intinya yaitu Tuhan, Manusia, Satu, Rakyat dan Adil. Masing-masing dapat diuraikan di bawah ini.

a. Hakekat Tuhan. Hakekat Tuhan dalam bentuk-bentuk pernyataan: zat yang mutlak, kausa prima, sangkan paraning dhumadhi, pencipta alam semesta, melompat tanpa kaki, mendengar tanpa telinga, berkata tanpa mulut, membau tanpa hidung, terbang tanpa sayap, pokoknya sesuatu yang tidak dapat dilukiskan seperti apa. Sebenarnya sifatsifat Tuahn: Maha Kuasa, Maha Esa, Maha bijaksana, Maha murah, Maha penyayang, Maha adil, Maha mengetahui, Maha mendengar, Maha pengampun, dan masih banyak lagi.

b. Hakekat Manusia. Terdapat dalam ajaran: a) monisme hakekat manusia terdiri atas satu asas misalnya air, api, udara, tanah, atom, roh, ide, materi. b) dualisme berpendirian bahwa manusia terdiri atas dua asas misalnya jiwa raga. c) Triadisme berpendirian bahwa manusia terdiri atas

\footnotetext{
7.Konstitusi Malawi 1994, menyatakan bahwa setiap orang harus mempunyai hak atas: a) tindakan adminstrasi yang sah dan adil menurut prosedur, yang dapat dibenarkan sehubungan dengan alasan-alasan bahwa hak-hak, kebebasankebebasan, harapan-harapan sah atau kepentingan-kepentingan sedang terusik atau terancam; dan b) dilengkapi dengan alasan tertulis bagi tindakan administratif, ketika hak-hak, kebebasan-kebebasan, harapan-harapan sah, atau kepentingan-kepentingan itu sudah diketahui. Lihat: Jeremy Pope, 1997, National Integrity System; Penerjemah: Iswira Laksana dkk, 1999, Pengembangan Sistem Integrasi Nasional, PTY. Jakarta, Pustaka Utama Grafiti, hlm105

8. Yanfei Zhou, “A Convergence Analysis on the Efficiency of Public Job Placement Services in Japan”, Japan Labor Review, Volume 5, No.1, Winter 2008, p. 59.

9.G. Kartasapoetra dkk, 1992, Hukum Perburuhan di Indonesia Berdasarkan Pancasila, Jakarta, Sinar Grafika, hlm 24.
} 
tiga asas misalnya yang dikemukakan oleh Aristoteles; materi-bentuk-nous, pluralisme berpendirian bahwa manusia terdiri atas banyak asas misalnya apiudara-air-tanah.

c. Hakekat Satu. Kata satu menunjukkan sesuatu yang mutlak tidak dapat dibagibagi lagi. Satu berarti mutlak terpisah dari sesuatu yang lain. Satu berarti bulat dan mempunyai eksistensi serta ciri-ciri sendiri.

d. Hakekat Rakyat. Rakyat adalah segenap penduduk suatu Negara, anak buah, orang kebanyakan atau orang biasa. Sebagaimana kita ketahui rakyat adalah salah satu syarat adanya negara. Rakyat adalah jumlah semua orang di dalam suatu negara. Rakyat adalah sejumlah manusia yang mendukung suatu negara. Kata kerakyatan mengandung pengertian dari, oleh dan untuk rakyat, artinya sesuatu yang mengenai rakyat.

e. Hakekat Adil. Adil diartikan: sebagai tidak berat sebelah, tidak sewenang-wenang, seimbang, perlakuan yang sama. Hakekat adil berarti memberikan kepada orang lain apa yang menjadi haknya. Hakekat adil berarti seimbangnya hak dan kewajiban. ${ }^{10}$

Hakekat dari kelima Isi dari sila-sila Pancasila tersebut, agar menjadi kaedah dalam pembentukan perundang-undangan ketenagakerjaan. Demikian juga dalam pelaksanaannya, menjadi pedoman bagi aparatur negara baik sebagai PNS dan Pegawai Pemerintah dengan Perjanjian Kerja di Kemenakertrans ataupun Disnakertrans.

Hakekat isi Pancasila merupakan norma dan tolok ukur bagi segala kegiatan kenegaraan, kemasyarakatan dan perorangan yang menyangkut nilai etika atau kesusilaan atau baik buruk. Dikatakan bermoral atau berkesusilaan atau bernilai etik jika sesuai dengan atau memenuhi syarat tolok ukur tersebut.

a. Etika Ketuhanan Yang Maha Esa. Ukuran moral ialah nilai-nilai yang terkandung di dalam dan sesuai dengan sifat-sifat Tuhan Yang Maha Esa.

b. Etika Kemanusiaan. Ukuran Moral ialah nilai yang terkadung di dalam dan sesuai dengan hakekat manusia. Misalnya, dikatakan bermoral kalau: 1) mengutamakan baik kebutuhan jasmani maupun rokhani, 2) mengutamakan baik kebutuhan individu maupun kepentingan masyarakat, 3) mengutamakan baik sebagai manusia yang berdiri sendiri dan sertanggung jawab maupun sebagai makhluk Tuhan.

c. 3.Etika Persatuan.Ukuran moral ialah nilai - nilai yang terkandung di dalam dan sesuai dengan hakekat satu. Misalnya, dikatakan bermoral kalau mengutamakan persatuan (Bhinneka Tunggal Ika).

d. 4.Etika Kerakyatan. Ukuran moral ialah nilai-nilai yang terkandung di dalam dan sesuai dengan hakekat rakyat. Misalnya, dikatakan bermoral kalau: gotong royong, musyawarah untuk mufakat, mengutamakan kepentingan semua buat semua, dan kebebasan disertai dengan pertanggung jawaban.

e. 5. Etika Keadilan.Ukuran moral ialah nilai-nilai yang terkandung di dalam dan sesuai dengan hakekat adil. Misalnya, dikatakan bermoral kalau: 1) mengutamakan baik hak maupun kewajiban secara seimbang, 2) adil terhadap diri sendiri, dan 3) adil terhadap Tuhan yaitu patuh menjalankan perintah-Nya dan menjauhi larangan-Nya. ${ }^{11}$

Hakekat Pancasila, merupakan inti sari dari nilai-nilai sila-silanya. Sedangkan etika Pancasila, merupakan ukuran moral yang terkandung dalam setiap sila-silanya. Kedua nilai dari hakekat dan moral tersebut, menjadi tolak ukur dari perbuatan seseorang apakah baik atau buruk. Hubungan industrial Pancasila (HIP) atau hubungan industrial Indonesia, berpedoman pada hakekat dan etika (moral) tersebut. Misalnya; Pengusaha dalam mengelola perusahaannya ternyata memperoleh untung besar, tentulah akan membagi keuntungannya dengan para pekerjanya. Apabila tidak, maka hakekatnya si pengusaha ini tidak memahami hakekat keadilan dari sila kelima. Kemudian moralnya dipertanyakan tentang hak dan kewajibannya dalam pembayaran upah pekerja dan hak-hak lain dari pekerja. 
Hakekat keadilan dari sila kelima tersebut, tidak lepas dari keinginan luhur dari Pendiri Republik Indonesia, didasari oleh landasan filosofis Pancasila untuk mencapai Indonesia yang lebih baik di masa depan. Keinginan tersebut tertuang dalam UUD NRI Tahun 1945, sebagai cita hukum bangsa Indonesia. B. Arief Sidharta menjelaskan, pertama, cita hukum bangsa Indonesia, berakar dalam Pancasila yang oleh para Pendiri Negara Republik Indonesia ditetapkan sebagai landasan kefilsafatan dalam menata kerangka dan struktur dasar organisasi negara sebagaimana dirumuskan dalam UUD NRI Tahun 1945. Cita-hukum Pancasila yang berakar dalam pandangan hidup Pancasila, dengan sendirinya akan mencerminkan tujuan nenegara dan nilai-nilai dasar yang tercantum dalam Pembukaan, dan Pasal-pasal UUD NRI Tahun 1945.

Kedua, pandangan hidup Pancasila bertolak dan keyakinan bahwa alam semesta dengan segala isinya, termasuk manusia, yang sebagai suatu keseluruhan terjalin secara harmonis, diciptakan oleh Tuhan. Kehadiran manusia di dunia dikodratkan dalam kebersamaan dengan sesamanya. Namun setiap manusia memiliki kepribadian yang unik yang membedakan yang satu dan yang lain. Keseluruhan pribadi manusia dengan keunikannya masing-masing mewujudkan satu kesatuan, yakni kemanusiaan. Jadi, "Kesatuan dalam Perbedaan". sebaliknya, dalam kebersamaan (kesatuan) itu setiap manusia individual warga kesatuan itu memperlihatkan kodrat kepribadian yang unik, yang berarti terdapatnya perbedaan di dalam kesatuan kemanusiaan. Jadi, "Perbedaan dalam Kesatuan".

Ketiga, pandangan hidup Pancasila dirumuskan dalam kesatuan lima sila yang masing-masing mengungkapkan nilai fundamental dan sekaligus menjadi lima asas operasional dalam menjalani kehidupan, termasuk dalam penyelenggaraan kegiatan menegara dan pengembanan hukum praktis. Berkaitan dengan sistem-nilai ini, Mochtar Kusumaatmadja mengemukakan bahwa dalam esensinya, sistem-nilai itu dapat dibedakan ke dalam nilai-dasar (base-values) sebagai landasan dan acuan untuk mencapai atau memperjuangkan sesuatu, dan nilaitujuan (goal-values) sebagai sesuatu yang harus dan layak untuk diperjuangkan atau diwujudkan. Sebagai sistem-nilai, Pancasila merupakan "Those-values" dan sekaligus juga merupakan "goal-values". Keseluruhan nilai dalam sistem-nilai Pancasila itu dipersatukan oleh asas "Kesatuan dalam Perbedaan" dan "Perbedaan dalam Kesatuan" yang menjiwai struktur dasar keberadaan manusia dalam kebersamaan itu. Dalam ungkapan tersebut terkandung pengakuan serta penghormatan terhadap martabat manusia individual, kekhasan kelompokkelompok etnis kedaerahan yang ada, dan keyakinan keagamaan dalam kesatuan berbangsa dan bernegara. ${ }^{12}$

Pancasila dalam kaedah kesatuan berbangsa dan bernegara, menjadi bintang pemandu atau leistren yang lapisan-lapisan materinya berisi substansi hukum dan tiang kerangka struktur hukum serta lingkungan kehidupannya adalah budaya hukum. Dardji Darmodihardjo menempatkan Pancasila sebagai sumber dari segala sumber hukum dengan menggambarkan gagasan dari Hans Kelsen tentang Reine Rechslehre, Grundnorm atau Unsprungnorm. Dardji Darmodihardjo menjelaskan bahwa Pancasila dibuat dalam arti digali oleh bangsa Indonesia yang merupakan jiwa dan kepribadian bangsa Indonesia sendiri. ${ }^{13}$

Sistem nilai dan asas yang berdasarkan cita hukum Pancasila, sudah merupakan kesepakatan bangsa. Bangsa Indonesia dengan Pancasila sebagai pandangan hidup, tentulah akan hidup secara terhormat dan bermartabat, baik untuk dirinya sendiri maupun untuk orang lain. Persoalannya, kenapa nilai dan asas yang berdasarkan Pancasila sulit untuk dilaksanakan dalam dalam kehidupan sehari-hari, karena nilainilai itu sudah dikalahkan oleh nilai-nilai asing. Nilai-nilai kapitalisme dan individualism, sudah merintangi nilai-nilai Pancasila dalam sistem Hukum Pengupahan, dimana pengusaha memandang pihak pekerja sebagai pihak lain dalam proses tawarmenawar. Fakta menunjukkan dalam konteks

12. B Arief Sidharta, Sebuah Gagasan tentang Paradigma Ilmu Hukum Indonesia; Op. Cit., hlm. 202-204.

13. Anthon F. Susanto, 2010, Ilmu Hukum Non Sistematik, Yokyakarta, Genta Publishing, hlm 294-295. 
demikian, dapat diyakini bahwa pekerja berada pada posisi tak berdaya yang harus patuh dengan tekanan pihak pengusaha. Sifat eksploitasi dan diskriminasi ini, pada akhirnya, hanya penguntungkan kapitalis terselubung dalam bingkai asas kekeluargaan.

Kesejahteraan menurut Tom Gunadi, telah dijamin UUD NRI Tahun 1945 dalam Pasal 33 dengan ketiga ayatnya, Pasal 34, Pasal 27 ayat 2 dan dapat juga ditambahka Pasal 23 dengan kelima ayatnya. Pemahaman terhadap nilai kesejahteraan tersebut, yaitu:

a. Bung Hatta merumuskan asas sosial yang disebut asas "kekeluargaan" itu dan membulatkannya dalam butir-butir penerapannya dalam bidang ekonomi. Istilah kekeluargaan menyodorkan kepada kita gagasan kunci yang harus ditumbuhkan hingga berbuah pada tiap tingkat pemikiran kita bangsa Indonesia mengenai ekonomi, sosial, dan politik.

b. Ekonomi kekeluargaan menjelajahi jalan tengah yang lebih dari pada sekedar kompromi dari kubu-kubu ekstrim yang bertentangan itu. Bung Hatta dalam banyak karya tulisnya telah meletakan dasar-dasar teori ekonomi yang asli. Kita para pewaris republik inilah yang berkewajiban mengembangkan ke dalam sistem pendapat ekonomi yang jelas bisa berdiri sendiri lepas dari - sekalipun terkoordinasi dengan-kedua kubu aliran ekstrim itu, yaitu klasikisme di satu pihak dan marxisme di pihak lain.

c. Ekonomi Pancasila atau ekonomi kekeluargaan dari Bung Hatta yang juga “ Bapak Koperasi" dan proklamator ini bersama Bung Karno pasti lebih dari sekedar koperasiisme belaka, dan jelas tak bias ditempatkan pada tingkat yang sama dengan distribusiisme atau ajaran tentang pembaruan moneter, dan sebagainya itu. Beliau telah meletakan dasar sistemasi pemikiran sosial Indonesia di bidang ekonomi dalam karya-karya tulisnya, pidato-pidatonya, dan dalam UUD NRI Tahun 1945, khususnya Pasal 33 didalamnya. Gagasan-gagasan Bung Hatta sendiri sudah dikemukakan dalam tulisantulisan dan pidato-pidato beliau sejak tahun-tahun awal 1930-an dan UUD NRI Tahun 1945 mendapatkan kekuatan hukumnya pada tanggal 18 Agustus 1945.

d. Pengertian keadilan sosial mencakup keadilan hukum dan keadilan dalam membagi (keadilan distributif) dalam kontradistinksi; perbedaan karena pertentangan dengan keadilan tukar menukar (keadilan komulatif) yang bersifat individual (keadilan individu). Keadilan sosial adalah suatu tipe keadilan yang khas pada masyarakat sebagaimana adanya objektif keadilan sosial adalah hak akan kesejahteraan sosial. Setiap warga negara untuk mengambil bagian dari nikmat kekayaan sosial. Oleh karena itu keadilan sosial menuntut pelaksanaan semua kewajiban dan realisasi semua hak yang objektifnya adalah kesejahteraan sosial. $^{14}$

Sistem ekonomi Pancasila mengandung unsur-unsur sebagai berikut:

a. Adanya unsur humanistis, dalam arti bahwa kegiatan ekonomi diarahkan kepada kepentingan orang banyak.

b. Adanya unsur kerjasama antara mereka yang melakukan kegiatan ekonomi, atau dapat dikatakan: tidak adanya suatu bentuk persaingan yang berkaitan merugikan pihak lain.

c. Adanya unsur keadilan sosial, dalam arti bahwa semuanya dapat menikmati kemampuan.

d. Adanya unsur bahwa kontribusi terhadap usaha menentukan jumlah bagian yang diterima dari usaha tersebut.

e. Adanya unsur bahwa kepentingan ekonomi bukan merupakan satusatunya yang dikejar.

f. Adanya unsur pengakuan terhadap kreativitas serta aktivitas rakyat. ${ }^{15}$

Pengakuan terhadap kreativitas serta aktivitas rakyat dalam menuju keadilan sosial masyarakat pekerja, telah dituangkan dalam UUK yang berlandaskan Pancasila dan UUD NRI Tahun 1945. Sedangkan Pembangunan ketenagakerjaan diselenggarakan atas asas keterpaduan dengan melalui koordinasi fungsional lintas sektoral pusat dan daerah,

14. Tom Gunadi, 1995, Ekonomi Pancasila, Dalam kancah Pendapat Ekonomi, Bandung, Angkasa, hlm hlm 3-10.

15. Haroso, 1997, Usaha Swasta dalam Sistem Ekonomi Pancasila; dalam: Mubyarto dkk (Editor), Ekonomi Pancasila, 
dengan tujuan: 1) memberdayakan dan mendayagunakan tenaga kerja secara optimal dan manusiawi; 2) mewujudkan pemerataan kesempatan kerja dan penyediaan tenaga kerja yang sesuai dengan kebutuhan pembangunan nasional dan daerah; 3) memberikan perlindungan kepada tenaga kerja dalam mewujudkan kesejahteraan; dan 4) meningkatkan kesejahteraan tenaga kerja dan keluarganya (Pasal 2,3, dan 4 UUK).

\section{Nilai-nilai dan Asas-asas dalam Cita Hukum Pancasila yang Seharusnya Mendasari Pengaturan Hukum Pengupahan}

Kerangka pandangan tentang keberadaan manusia, cita hukum Pancasila berintikan: 1) Ketuhanan Yang Maha Esa; 2) Penghormatan atas martabat manusia; 3) Wawasan Kebangsaan dan Wawasan Nusantara; 4) Persamaan dan kelayakan; 5) Keadilan sosial; 6) Moral dan budi pekerti yang luhur; dan 7) Partisipasi dan transparansi dalam proses pengambilan putusan publik. Sedangkan ciri-ciri negara hukum Pancasila : 1) keserasian hubungan antara pemerintah dan rakyat berdasarkan asas kerukunan; 2) hubungan fungsional yang proposional antara kekuasaan-kekuasaan negara; 3) prinsip penyelesaian sengketa secara musyawarah dan peradilan merupakan sarana terakhir; dan 4) keseimbangan antara antara hak dan kewajiban. ${ }^{17}$

Hukum mengemban fungsi ekspresif, yakni mengungkapkan pandangan hidup, nilai-nilai budaya, dan keadilan. Di samping itu, hukum juga mengemban fungsi instrumental, yakni sarana untuk menciptakan dan memelihara ketertiban, stabilitas, dan prediktabititas; sarana untuk melestarikan nilai-nilai budaya dan mewujudkan keadilan, sarana pendidikan dan pengadaban masyarakat; sarana mewujudkan kemakmuran dan kesejahteraan masyarakat; serta sarana untuk pembaharuan masyarakat (mendorong, mengkanalisasi dan mengarahkan perubahan masyarakat). Dalam masyarakat pascakolonial yang sedang menjalani perubahan sosial yang fundamental dan mencakup seluruh bidang kehidupan secara simultan, perundang-undangan memegang peranan dominan dalam pembangunan tata hukum nasional serta menjalankan fungsi hukum sebagai sarana pendidikan dan perubahan masyarakat. Yurisprudensi berperan untuk mendukung dengan menjabarkan ketentuan perundangundangan dalam putusan konkretnya. Dalam kaitan ini, maka Ilmu Hukum yang adekuat sangat dibutuhkan sebagai sarana intelektual untuk membantu proses pembentukan hukum melalui perundang-undangan dan yurisprudensi serta membantu penyelenggaraan hukum menjalankan fungsi hukum sebagai sarana pendidikan dan pembaharuan masyarakat.

Sebelumnya Mochtar Kusumaatmadja menguraikan nilai-nilai ${ }^{18}$ yang terkandung dalam sila-sila Pancasila:

a. Ketuhanan Yang Maha Esa terkandung nilai religius: a) kepercayaan terhadap adanya Tuhan Yang Maha Esa sebagai Pencipta segala sesuatu dengan sifatsifat yang sempurna dan suci seperti Mahakuasa, Maha Pengasih, Maha adil, Maha bijaksana, dan sebagainya; dan b) ketakwaan terhadap Tuhan Yang Maha Esa, yakni menjalankan semua perintahNya dan menjauhi larangan-Nya.

b. Kemanusiaan yang adil dan beradab terkandung nilai kemanusiaan: a) pengakuan terhadap harkat dan martabat manusia dengan segala hak dan wajib asasinya, dan b) perlakuan yang adil terhadap sesama manusia, terhadap diri sendiri, alam sekitar, dan terhadap Tuhan, dan c) manusia sebagai makhluk beradab atau berbudaya yang memiliki daya cipta, rasa, karsa, dan keyakinan.

c. Persatuan Indonesia terkandung nilai persatuan bangsa: a) pengakuan terhadap Bhinneka Tunggal Ika suku bangsa (etnis), agama, adat istiadat, kebudayaan, b) pengakuan terhadap persatuan bangsa dan wilayah Indonesia serta wajib membela dan menjunjung tingginya (patriotisme), dan c) cinta dan bangga akan bangsa dan Negara Indonesia (nasionalisme).

16. B Arief Sidharta, Sebuah Gagasan tentang Paradigma Ilmu Hukum Indonesia; Ibid.

17. Lieke Lianadevi Tukgali, 2010, Fungsi Sosial Hak Atas Tanah, Jakarta, Gramedia, hlm 178.

18. Ibid, hlm. 208. 
d. Kerakyatan yang dipimpin oleh hikmat $\mathrm{k}$ e b i j a k a n a n d a 1 a m permusyawaratan/perwakilan terkandung nilai kerakyatan: a) negara adalah untuk kepentingan seluruh rakyat, b) kedaulatan adalah di tangan rakyat, c) manusia Indonesia sebagai warga Negara dan warga masyarakat mempunyai kedudukan, hak, dan kewajiban yang sama, d) pemimpin kerakyatan adalah hikmat kebijaksanaan yang dilandasi akal sehat, dan e) keputusan diambil berdasarkan musyawarah untuk mufakat oleh wakilwakil rakyat.

e. Keadilan Sosial bagi Seluruh rakyat Indonesia terkandung nilai keadilan sosial: a) perlakuan yang adil di segala bidang kehidupan terutama di bidang politik, ekonomi, dan sosial budaya; b) perwujudan keadilan sosial itu meliputi seluruh rakyat Indonesia, c) keseimbangan antara hak dan kewajiban, d) menghormati hak milik orang lain, e) cita-cita masyarakat adil dan makmur yang merasa material dan spiritual bagi seluruh rakyat Indonesia, dan f) cinta akan kemajuan dan pembangunan. ${ }^{19}$

Asas kekeluargaan menurut Padmo Wahyono dalam Negara Hukum Pancasila yang tercantum dalam UUD NRI Tahun 1945, mengutamakan adalah "rakyat banyak, namun harkat dan martabat manusia tetap dihargai". Pasal 33 UUD NRI Tahun 1945 mencerminkan secara khas asas kekeluargaan ini. Dalam pasal ini ada suatu penjelasan bahwa yang penting ialah kemakmuran masyarakat dan bukan kemakmuran orang seorang. Untuk dapat memahami bagaimana konsep Negara Hukum Pancasila, perlu ditelaah bagaimana pengertian negara dan pengertian hukum dilihat dari sudut asas kekeluargaan itu. Padmo Wahyono memahami hukum adalah suatu alat atau wahana untuk menyelenggarakan kehidupan negara atau ketertiban, dan menyelenggarakan kesejahteraan sosial. ${ }^{20}$ Kesejahteraan rakyat banyak ini, dimaksudkan adalah keadilan substantif.

Konsep negara kesejahteraan, bahwa negara tidak hanya pasif menjaga keamanan warga negara saja, seperti yang disebut dengan istilah negara "penjaga malam". Melainkan, dengan konsep negara kesejahteraan ini, negara aktif juga untuk mensejahterakan rakyatnya, dengan menjalankan program-program kesejahteraan sosial dan demokratis bagi rakyatnya secara luas, seperti menjediakan pendidikan gratis, pengobatan gratis atau asuransi kesehatan yang meluas, biaya jaringan pengaman sosial (social safety net), memperhatikan kehidupan orang-orang terlantar, bantuan terhadap ekonomi kecil, menyediakan bantuan hukum cuma-cuma bagi mereka yang tidak mampu, pemberian hak-hak sipil rakyat dan hak-hak demokrasi, bahkan bila perlu, pemberian bantuan/tunjangan terhadap para penganggur, dan melaksanakan hal-hal lain yang menyangkut dengan kesejahteraan rakyat. ${ }^{21}$

Rakyat yang tidak sejahtera, dikarenakan pemerintah yang melaksanakan hukum tidak berdasarkan moral. ThomasAquinas menyatakan, harus ada dasar moral bagi hukum positif. Hukum dapat tidak adil, karena bertentangan dengan kesejahteraan manusia. Hal ini terjadi karena tiga hal: 1) karena penguasa memaksakan hukum yang tidak membawa kesejahteraan umum, tetapi semata-mata karena keinginan

19. Teguh Prasetyo dan Abdul Halim Barkatullah, 2012, Filsafat, Teori dan Ilmu Hukum; Pemikiran menuju Masyarakat yang Berkeadilan dan Bermartabat, Kota Depok, PT. Raja Grafindo Persada, hlm 373-375; Lihat: Mochtar Kusumaatmadja, Pemantapan cita hukum dan Asas-asas Hukum Nasional di Masa kini dan Masa yang akan datang; dalam: Majalah Hukum Nasional No. 1, Tahun 1995, Jakarta, BPHN Departemen Kehakiman, hlm 97. Lihat: Soejadi, 1999, Pancasila Sebagai Sumber Tertib Hukum Indonesia, Yokyakarta, Lukman Offset, hlm 98-99.

20. H.Muhammad Tahir Azhary, 2004, Negara Hukum, Suatu Studi tentang Prinsip-prinsipnya Dilihat dari Segi Hukum Islam, Implementasinya pada Priode Negara Madinah dan Masa Kini, Jakarta, Prenada Media, hlm 94-95.

21.Konsep negara berkesejahteraan sosial dari Darmawan Triwibowo adalah gagasan yang telah lama dicetuskan oleh Otto von Bismarck pada tahun 1850 di Prusia. Di Amerika Serikat, konsep negara bersejahteraan sosia) yang berasal dari Eropa ini berbenturan dengan konsep negara liberal kapitalistik (yang berlandaskan kepada konsep ekonomi pasar bebas). Tetapi kemudian, kedua konsep tersebut mengalami konvergensi sehingga kenyataan empiris kemudian menunjukkan bahwa baik yang terjadi di Eropa maupun yang terjadi di Amerika Serikat sama-sama menjadikan negara-negara tersebut menjadi negara dengan rakyatnya yang hidup sejahtera; Munir Fuady, 2010, Konsep Negara Demokrasi, Bandung, Refika Aditama, hlm 55. 
penguasa sendiri; 2) karena pembuat hukum melampaui kewenangan yang dimilikinya; dan 3) karena hukum dipaksakan kepada masyarakat secara tidak sama, meskipun alasannya demi kesejahteraan umum. Mengingatkan apa yang dikatakan Agustinus: "Suatu hukum yang tidak adil sama sekali bukanlah hukum". Pandangan yang demikian bertentangan dengan positivisme hukum yang tidak menerima hubungan antara hukum dengan moralitas. ${ }^{22}$ Positivisme hukum sebagai sebuah pendirian lugas yang menyatakan bahwa sama sekali tidak benar bila hukum-hukum adalah reproduksi atau pemenuhan ketentuan moralitas, meskipun dalam faktanya hal itu yang kerap kali terjadi. Hukum dengan moralitas, berdampak pada kesejahteraan manusia.

Suatu perbedan cara memahami thesis hukum alam, karena hukum menawarkan kesejahteraan manusia. Hal umum yang baik, apabila hukum gagal dalam memenuhi tuntutan ini (kesejahteraan manusia), maka bukanlah hukum. Pandangan tentang hukum klasik oleh John Finninn, telah menimbulkan banyak argumentasi bahwa sifat dasar hukum adalah untuk melayani kebaikan; hukum tanpa peradilan bukanlah hukum, karena ia gagal dalam memenuhi tuntutan ini, meskipun ketika ia dipakai oleh aparat hukum. Karena kegagalan ini, hukum seperti itu tidak memiliki klaim, atau memiliki klaim yang lemah dibandingkan hukum lainnya. ${ }^{24}$

Konsideran UUK tersebut, merupakan aspirasi filosofis dari negara untuk mensejahterakan rakyat, khususnya di bidang ketenagakerjaan. Moral hukum ketenagakerjaan ini yang dapat mengantarkan pekerja untuk menikmati janji-janji negara kesejahteraan. Namun niat baik sebagian pengusaha dalam pembayaran upah yang berkeadilan substantif, masih jauh dari harapan. Sebab kenaikan UMP setiap tahun dari para pengusaha melalui Apindo/Kadin, selalu minta penangguhan kenaikan tersebut pada Pemerintah Daerah setempat. Hal ini telah menimbulkan gelombang demontrasi pekerja. Bagi pekerja juga timbul masalah baru, yaitu kesulitan pekerja mendapatkan pekerjaan baru, dikarenakan salah satunya adalah tidak berfungsinya pasar kerja (Labor Market). Pemikiran yang serupa dari Zen Zanibar, bahwa persoalan ketenagakerjaan adalah persoalan penyediaan tenaga kerja dalam membangun bisnis. Bagi pengusaha mana pun tenaga kerja adalah soal sangat penting baik dari segi kualitas (kompetensi, pengalaman dan mental) maupun kuantitas (sedikit tenaga kerja dengan kinerja baik) untuk kebutuhan kinerja yang efisien. Dalam tema ini issu penting, adalah peranan pekerja untuk dapat berpartisipasi dalam pengembangan bisnis dalam kerangka pasar bebas. ${ }^{25}$ Kesulitan pekerja mendapatkan pekerjaan baru, juga karena perkembangan teknologi yang mana teknologi tersebut dapat mengurangi peranan manusia pada bidangbidang pekerjaan tertentu. Dalam hal ini, pertimbangan rechtsidee Pancasila menentukan pilihan-pilihan teknologi menengah yang bersifat padat karya agar dapat menyerap lapangan pekerjaan.

Salah satu solusi dalam penciptaan lapangan kerja ini, dengan melaksanakan asas-asas pemerintahan yang baik. Menurut Yanfei Zhou dengan memberikan layanan penempatan kerja umum, membantu secara serentak antara penawar kerja dengan pencari kerja. Tujuannya adalah untuk memproduksi secara besar-besaran pekerjaan berkualitas tinggi yang memenuhi persyaratan bagi kedua belah pihak dan untuk membantu "underdog dalam bursa kerja" dengan menanggung "biaya pemasangan", atau biaya pencarian kerja dari kedua belah pihak. Penetapan tunjangan penganguran merupakan kebijakan

22. M. Sastrapratedja, 2002, Kata Pengantar Etika Hukum; dalam: E. Sumaryono, Etika Hukum, Relevandi Teori Hukum Kodrat Thomas Aquinas, Kanasius, Yokyakarta, Kanasius, hlm 11.

23.Hart, H.L.A., 2009, The Consept of Law, Clarendon Press-Oxford, New York, 1997; Penerjemah: M. Khozim, Konsep Hukum. Bandung, Nusa Media, hlm 287, John Austin, menyatakan, bahwa: moral terpisah dari hukum, moral di satu pihak dan hukum di pihak lain. Hakekat dari hukum adalah perintah. Semua hukum positif adalah perintah dari yang berdaulat/penguasa. Pandangannya bertolak belakangan dengan hukum alam atau mazhab sejarah; Lihat: Lili Rasjidi, 1990, Dasar-Dasar Filsafat Hukum, Bandung, PT. Citra Aditya Bakti, hlm 42.

24. Kent Greenawalt, 1996, Too Thin and Too Rich Distinguishing Features of Legal Positivism, dalam: Robert P. George, The Outonomy of Law, Esssays on Legal Positivism, New York, Oxford University, hlm 9.

25. Zen Zanibar, Mei 2012, Perizinan dan Ketenagakerjaan, Fenomena Otonomi Daerah Merespons Pasar Global, Jurnal Simbur Cahaya XVII (48), Fakultas Hukum Universitas Sriwijaya Inderalaya, hlm 3184. 
pasif di bursa tenaga kerja. Sedangkan layanan penempatan kerja umum merupakan kebijakan yang aktif, karena pemerintah secara aktif terlibat dalam bursa tenaga kerja. Kebijakan tersebut, haruslah didukung oleh Undang-undang Ketenagakerjaan yang berwibawa dalam arti dapat diterima oleh pengusaha dan pekerja. Menurut Ida Susanti, untuk mewujudkan rechtsidee di dalam hubungan industrial, kita harus menelusuri jejak Pancasila di dalam peraturan/hukum positif yang berkaitan dengan hubungan industrial. Pertama, Kaedah Ketuhanan Yang MahaEsa, berkaitan dengan pekerja dalam persoalan menjalankan ibadah, ada hubungan antara antara Pasal 5 dan 6 UUK yang melarang terjadinya diskriminasi terhadap pekerja untuk memperoleh pekerjaan dan melarang perlakuan diskriminatif dari pengusaha. Indonesia sendiri telah meratifikasi Konvensi ILO Discrimination (Employment and Occupation) Convention, 1958 (No. 111) yang telah diratifikasi pada tanggal 7 Juni 1999 melalui8 UU. No. 21 tahun 1999 tentang Pengesahan Konvensi ILO No. 111 mengenai Diskriminasi dalam Pekerjaan dan Jabatan. Dalam Konvensi ini, agama adalah salah satu dasar untuk melarang dilakukannya diskriminasi terhadap seorang pekerja. Konvensui ILO No. 111, jelas bahwa ternyata sila pertama ini bukan hanya dikenal di Indonesia, melainkan juga nilai universal yang telah diterima oleh negara-negara yang telah meratifikasi konvensi ILO ini.

Kedua, Keadilan Sosial bagi Seluruh Rakyat Indonesia tercapai, apabila hukum berfungsi dalam masyarakat. Fungsi hukum yaitu:1) Fungsi Memfasilitasi, dalam hal ini termasuk memfasilitasi sehingga tercapai suatu ketertiban; 2) Fungsi Represif, dalam hal ini termasuk penggunaan hukum sebagai alat bagi elite berkuasa untuk mencapai tujuan-tujuannya, 3) Fungsi Ideologis, dalam hal ini termasuk menjamin pencapaian legitamasi, hegemoni, dominasi, kebebasan, kemerdekaan, keadilan, dan lain-lain, dan 4) Fungsi Reflektif, dalam hal ini merefleksi keinginan bersama dalam masyarakat sehingga mestinya hukum bersifat netral. ${ }^{28}$

Sedangkan seorang sosiologi hukum, yaitu Podgorecki, menyatakan: Fungsi hukum dalam masyarakat adalah sebagai berikut: a) Fungsi Integrasi, yakni bagaimana hukum merealisasi saling berharap (mutual expectation) dari masyarakat; b) Fungsi Petrifikasi, yakni bagaimana hukum melakukan seleksi dari pola-pola perilaku manusia agar dapat mencapai tujuan-tujuan sosial; c) Fungsi Reduksi, yakni bagaimana hukum menyeleksi sikap manusia yang berbeda -beda dalam masyarakat yang kompleks sehingga sesuai dengan kebutuhan masyarakat. Dalam hal ini, hukum berfungsi untuk mereduksi kompleksitas ke dalam pembuatan putusan-putusan tertentu; d) Fungsi Memotivasi, yakni hukum mengatur agar manusia dapat memilih perilaku yang sesuai dengan nilai-nilai masyarakat; dan e) Fungsi Edukasi, yakni hukum bukan saja menghukum dan memotivasi masyarakat, melainkan juga melakukan edukasi dan sosialisasi. $^{29}$

Keseimbang dan harmonis dalam hubungan kerja antara pekerja dan pengusaha, jika menggunakan pendapat Roberto $M$. Unger, sesuatu itu, dimulai dari struktur gagasan yang berlaku tentang kontrak dan semua bidang yang terkait dengannya dalam bentuk dua pasang: prinsip dan prinsiptandingan. Prinsip yang pertama, adalah kebebasan untuk menjalin atau menolak menjalin kontrak. Lebih khusus lagi, ini terkait dengan kebolehan Anda memilih rekanan kontrak anda. Untuk sementara hal ini dapat disebut sebagai kebebasan untuk

26. Yanfei Zhou, A Convergence Analysis on the Efficiency of Public Job Placement Services in Japan, Japan Labor Review, 5 (1) Winter 2008, hlm 59.

27.L.H. Garstin menguraikan tentang isi dari pada ideology yang pada umumnya terdiri dari komponen-komponen berikut: 1) suatu pola pemikiran atau falsafah tentang alam semester, seperti kegaiban jagat, pacuan sejarah, dan nasib manusia; 2) suatu gagasan tentang makna hidup di dunia ini atau analisa tentang kondisi kehidupan manusia kini menurut pandangan falsafah tersebut, 3) suatu pengharapan yang terumus pada tujuan hidup atau proyeksi tentang maa depan, dan 40 suatu minat tentang peranan manusia dalam mencapai tujuan tersebut; Lihat: Albert Widjaya, 1988, Budaya Politik dan Pembangunan Ekonomi, Jakarta, LP3ES, hlm 4

28. Munir Fuady, 2007, Sosiologi Hukum Kontemporer Interaksi Hukum, Kekuasaan, dan Masyarakat, Bandung, PT. Citra Aditya Bakti, hlm 58.

29. Ibid., hlm 59 . 
berkontrak. Kualifikasi yang digariskan oleh hukum kewajiban pada doktrin 'privity' (pandangan bahwa secara hukum kontrak hanya mengikat pihak-pihak yang langsung berkontrak atau kontraktor-umum, tidak mengikat pihak ketiga atau sub-kontraktor) menunjukkan bahwa prinsip kebebasan berkontrak mengandung kompleksitas makna tertentu meskipun ketika bentuk organisasi pasar yang dominan saat ini dianggap lumrah. Kedua, prinsip tandingan bahwa, wilayah lain hukum dan doktrin, memang membatasi prinsip kebebasan berkontrak atas nama gagasan yang sama sekali berbeda. Mereka berupa sebuah prinsip tandingan bahwa: "kebebasan untuk memilih rekanan kontrak tidak akan diperbolehkan dijalankan dengan cara mengabaikan aspek komunal kehidupan sosial" ${ }^{30}$

Sedangkan Atiyah, mengkaji dari aspek tujuan dasar dari kontrak: 1) memaksa suatu janji dan melindungi harapan wajar yang muncul darinya, 2) mencegah memperkaya diri sendiri yang dilakukan secara tidak adil, dan 3) mencapai keseimbangan antara kepentingan sendiri dan kepentingan terkait dari pihak lawan. Soepomo juga mengatakan, hukum mengharapkan dari para pihak kemampuan untuk bersikap menjaga kepantasan sosial, baik satu pihak terhadap pihak lainnya, maupun terhadap semua orang yang mungkin terlibat didalam suatu transaksi. ${ }^{32}$

Upah yang selama ini sebagai bagian dari proses tawar-menawar antara pekerja dan pengusaha, harus memperhatikan keseimbangan dan prinsip tandingan dengan memasuki wilayah-wilayah hukum progresif, seperti dalam konteks Arrest Hoge Raad 1919 dalam kasus Lindenbaum dan Cohen. Pembayaran upah pekerja tidak saja berdasarkan prinsip tawar-menawar "yang tidak seimbang antara pekerja dan pengusaha", tetapi memperhatikan kaedahkaedah sosial di masyarakat, seperti kepatutan, kepantasan dan kewajaran dalam membayarakan upah dengan nilai-nilai kemahalan harga kebutuhan pokok pekerja. Keadilan dalam hubungan kerja, adalah bagaimana agara pekerja dan pengusaha sama-sama adil dan sejahtera. Menurut John Stuart Mill, sumber dari kesadaran keadilan itu bukan terletak pada kegunaan, melainkan rangsangan untuk mempertahankan diri dan perasaan simpati. Hakekat keadilan mencakup semua persyaratan moral yang sangat hakiki bagi kesejahteraan umat manusia. ${ }^{33}$

Jika prinsip tandingan dalam prinsip kebebasan berkontrak ini dilaksanakan oleh pengusaha, maka akan menampilkan fungsi integrasi. Hukum merealisasikan sikap saling berharap (mutual expectation) dari antara kedua belah pihak, menjadi nilai harmoni untuk mencapai tujuan bersama. Beberapa bentuk kearifan lokal dalam mencapai tujuan bersama pada masyarakat pedesaan Sumatera Selatan, khususnya di daerah Ranau Kab. OKU Selatan, antara lain:

a. Asas belin. Asas ini berupa menerapkan pola gotong royong yang disebut "belin". Belin ini dilakukan ketika mengetam padi dan memetik kopi, masyarakat secara bersama-sama sekampung mengetam padi pada salah satu anggota dalam satu hari. Pada hari esoknya mengetam di anggota yang lain dan seterusnya. Manfaat dari asas belin ini: a) masyarakat bekerja dengan etos kerja yang tinggi karena bersamasama; b) bekerjanya dengan riang gembira dan tidak merasa sepi; c) hasil panennya utuh milik sendiri, tanpa adanya upah atau bagi hasil dari panen tersebut; d) jika dikerjakan orang lain dari luar desa, maka padi sebagai asset desa, akan berkurang dari desa karena dibawa oleh pekerja tadi.

b. Asas saling berharap(silaturrahmi). Masyarakat desa saling membutuhkan satu sama lainnya, maka mereka saling berharap atau tidak putus harapan. Oleh karen itu, mereka berusaha untuk menghidarkan konflik antar sesama, karena nantinya mereka akan saling

\footnotetext{
30. Roberto Mangabeira Unger, 1983, The Critical Legal Studies Movement, Cambridge University Press, London, Penerjemah: Narulita Yusron, Gerakan Studi Hukum Kritis, Bandung, Nusa Media, 2012, hlm 98-99.

Herlien Budiono, 2006, Asas Keseimbangan bagi Hukum Perjnjian Indonesia, Hukum Perjanjian Berdasarkan Asas-asas Wigati 31. Indonesia, Bandung, Citra Aditya Bakti, hlm 310.

32. Ibid. $\operatorname{hlm} 311$.

33. Lili Rasjidi, 1993, Filsafat Hukum, Apakah Hukum itu; Bandung, PT. Remaja Rosdakarya, hlm 46.
} 
berharap pertolongan yang lain. Di samping itu, secara budaya mereka punya hubungan persaudaraan dan perkawinan yang mengikatkan mereka pada kepentingan yang sama.

c. Asas himpun bumekon. Masyarakat desa sebelum melangsung perkawinan anaknya, maka diadakan musyawarah dari wakilwakil suku dalan desa itu yang disebut "himpun'. Ketika acara himpun telah dilakukan dan diketahui oleh masyarakat seluruh desa, maka mereka semua akan datang tanpa diundang lagi dan membantu barang, makanan, uang atau tenaga agar pelaksanaan perkawinan itu terlaksana tanpa memberatkan orang tua mempelai atau penganten. ${ }^{34}$

Ketiga kearifan lokal ini sebenarnya dapat diterapkan dalam hubungan industrial dan diangkat menjadi sandaran kebijakan ketika membuat PKB. Pertama, asas belin, dapat dijadikan salah satu pasal PKB yang intinya perusahaan dan para pekerja harus membantu berupa tenaga, uang dan bahanbahan pokok ketika salah satu pekerja mengunduh mantu; kedua, asas saling berharap (silaturrahmi), dapat dijadikan salah satu pasal PKB yang intinya pengusah dan pekerja adalah satu rumah tangga besar, harus berupaya menghindarkan konflik karena nantinya mereka akan saling berharap bantuan satu sama lain; dan ketiga, asas himpun bumekon, dapat dijadikan salah satu pasal dalam PKB yang intinya apabila pengusaha dan SP/SB telah bersepakat dalam $\mathrm{PKB}$, maka otomatis pengusaha dan para pekerja menerima keputusan itu dengan ikhlas.

Ketiga kearifan lokal tersebut yang sudah dimuat dalam PKB dapat menjadikan Hubungan industrial menjadi harmonis. Kelangsungan berusaha dan bekerja pada suatu perusahaan, bertujuan untuk memperoleh penghidupan bersama yang layak bagi kemanusiaan, dan hak setiap orang untuk mendapat imbalan dan perlakuan yang adil dan layak dalam hubungan kerja.

Sementara itu, Indonesia juga telah meratifikasi Kovenan Internasional tentang Hak-hak ekonomi, sosial, dan budaya; juga telah mengakui hak setiap orang untuk mencari nafkah melalui pekerjaan yang dipilih atau diterimanya secara bebas. Dengan demikian, masyarakat yang adil dan makmur ini ternyata dicita-citakan oleh bangsa Indonesia. ${ }^{35}$

Namun untuk ketertiban dan ketenteraman suatu tatanan masyarakat (social order) tercipta pada hakikatnya merupakan produk masyarakat yang berlangsung secara terus-menerus yang timbul dan berkembang memperbaharui diri sebagai suatu proses, pembiasaan ini terkristalisasi menjadi kebiasaan (falkways). Kebiasaan dalam perkembangannya menimbulkan kesadaran bersama mengenai tindakan-tindakan yang dianggap baik patut maupun lazim yang akan diformulasikan sebagai tata kelakukan (mores). Tata kelakuan akan direpsepsi sebagai kaidah hukum, baik hukum yang sifanya tertulis (undang-undang) maupun tidak tertulis. Sepanjang menyangkut hukum tertulis, akan ada tata cara atau prosedur membentuk kaidah hukum baru. Tidak demikian kaidah tidak tertulis, yang tidak diketahui saat terjadi dan saat surut sebagai hukum. Meskipun dalam kaidah hukum tertulis tersedia suatu tata cara, tetapi tidak mudah dilakukan, selain tidak untuk membentuk, mengubah dan mengganti yang sudah ada. Dipihak lain masyarakat senantiasa berubah dan memerlukan kaidah hukum yang tepat dengan perubahan masyarkat. Peristiwa hukum senantiasa terjadi dan harus diselesaikan setiap waktu yang juga memerlukan penerapan kaidah hukum yang tepat, benar, dan adil. ${ }^{36}$ Kesemua pristiwa tersebut harus dituntun oleh nilainilai yang berlaku di masyarakat. Nilai-nilai yang terdapat dalam masyarakat pekerja, berkehidupan sesuai dengan konsep Negara

\footnotetext{
34. Hasil pengamatan dan pengalaman penulis sebagai putera daerah Ranau, Kab. OKU Selatan.

35. Ida Susanti, 2011, Merajud Nilai-Nilai Pancasila ke dalam Hukum Nasional tentangt Hubungan Industrial., Dalam: Elly Erawaty dkk, Beberapa Pemikiran Tentang Pembangunan Sistem Hukum Naional Indonesia, Bandung, Citra Aditya Bakti, hlm 273-283.

36. Catur Iriantoro, "Kedudukan dan Relevansi Yurisprudensi untuk mengurangi Disparitas Putusan Perdata", Majalah Varia Peradilan, No 312 November 2011, hlm 105.
} 
hukum berdasarkan Pancasila menurut UUD NRI Tahun 1945, tentu saja mengandung jiwa dan semangat Pancasila, yang oleh Philipus M. Hadjon disebutnya "jiwa dan isi Negara Hukum Pancasila" ${ }^{37}$

Berfungsinya hukum dalam masyarakat ketenagakerjaan, didasarkan pada jiwa dan isi Negara Hukum Pancasila, pabila telah memperoleh keadilan substantif, bukan seperti saat ini adalah keadilan prosedural. Artinya fungsi hukum belum terlaksana dalam memanusiakan masyarakat pekerja. Pengusahan dalam kesehari-hariannya baru berempati dalam kata-kata, tetapi sikap dan prilaku menampilkan kehidupan yang mewah dihadapan para pekerjanya Oleh karena itu, sistem nilai dan asas-asas hukum pengupahan harus bersendikan kelima sila-sila Pancasila.

Rechtsidee dari Pancasila yang bersumber dari nilai-nilai di masyarakat, harus tercermin dan dituangkan di dalam hubungan industrial, agar dalam pelaksanaanya dapat menuntun pihak-pihak dalam hubungan industrial tersebut. Sehingga tujuan dari hukum ketenagakerjaan menjadikan pekerja dan pengusaha harmonis dalam bekerja dan tercapai keadilan prosedural serta keadilan substantif. Apabila pekerja dan pengusaha sudah harmonis, maka tidak ada penilaian yang akan dilakukan terhadap kedua belah pihak oleh pihak ketiga.

\section{Simpulan}

Berdasarkan pembahasan dan analisis di atas, dapat disimpulkan sebagai berikut:

1. Hakekat Pancasila merupakan inti sari dari nilai-nilai sila-silanya, sedangkan etika Pancasila, merupakan standar moral yang terkandung dalam setiap silasilanya. Kedua nilai dari hakekat dan moral tersebut, menjadi tolak ukur dari perbuatan seseorang apakah baik atau buruk. Hubungan industrial Pancasila (HIP) atau hubungan industrial Indonesia, berpedoman pada hakekat dan etika (moral) tersebut. Ketika Pengusaha dalam mengelola perusahaannya memperoleh untung besar atau kecil, tentulah akan membagi keuntungannya dengan para pekerjanya. Apabila tidak, maka pengusaha ini tidak memahami hakekat keadilan dari sila kelima. Kemudian moralnya dipertanyakan ketika tidak adil terhadap para pekerjanya.

2. Keadilan prosedural yang merupakan upaya-upaya Aparatur Sipil Negara (Kemenakertrans/Disnakertrans), pengusahan dan pekerja dalam pencapaian keadilan substantif. Substansi dari nilai-nilai Pancasila belum terlaksana dalam sehari-hariannya, karena pengusaha berkutat dalam pembelaan diri dengan kesulitan atau kondisi perusahaan yang terkesan selalu merugi. Namun dalam kehidupan keseharian, menampilkan kehidupan yang mewah dihadapan para pekerjanya. Oleh karena itu, Rechtsidee dari Pancasila yang bersumber dari nilai-nilai di masyarakat atau kearifan lokal, harus tercermin dan dituangkan di dalam hubungan industrial dalam bentuk PKB. Hukum pengupahan, wajib menjadikan pekerja dan pengusaha harmonis yang didasarkan pencapaian keadilan prosedural dan keadilan substantif. Apabila pekerja dan pengusaha sudah harmonis, maka tidak ada penilaian yang akan dilakukan terhadap kedua belah pihak oleh pihak ketiga.

3. Keadilan sosial dalam hukum pengupahan adalah keadilan substantif yang mensejahterakan masyarakat pekerja. Pengusaha dan pekerja, memperoleh bagian masing-masing dari keuntungan nilai tambah hasil industri dan jasa. Oleh karena itu keadilan sosial dalam sistem hukum pengupahan, terpenuhi kebutuhan pokok, kebutuhan sekunder, dan dapat menabung (saving) sebagian penghasilan untuk pristiwa-peristiwa penting bagi keluarga pekerja yang segera dilaksanakan. Demikian juga dalam

37. Jiwa dan isi Negara Hukum Pancasila: a) Negara menghendaki keserasian hubungan antara pemerintah dan rakyat berdasarkan asas kerukunan; b) Terjalinnya hubungan fungsional yang proporsional antara kekuasaan-kekuasaan negara; c) Penyelesaian sengketa secara musyawarah, sedangkan peradilan merupakan sarana terakhir; dan d) Menekankan hak asasi manusia yang seimbang dengan kewajiban asasi manusia. Lihat: Muhammad Syaifuddin, "Nasionalisasi Perusahaan Modal asing Ide Normatif Pengaturan Hukumnya Dalam UU NO. 25 Tahun 2007 Dan Relevansinya Dengan Konsep Negara Hukum Kesejahteraan Pancasila Dalam UUD 1945", Jurnal Simbur Cahaya XVII (47) Fakultas Hukum Universitas Sriwijaya, Januari 2012, hlm. 2835. 
kehidupan sehari-hari, dapat hidup berdampingan dan bergaul dalam masyarakat secara terhormat dan bermartabat.

\section{DAFTAR PUSTAKA}

Azhary, H. Muhammad Tahir, 2004, Negara Hukum, Suatu Studi tentang Prinsipprinsipnya Dilihat dari Segi Hukum Islam, Implementasinya pada Priode Negara Madinah dan Masa Kini, Jakarta: Prenada Media.

Budiono, Herlien, 2006, Asas Keseimbangan bagi Hukum Perjnjian Indonesia, Hukum Perjanjian Berdasarkan Asasasas Wigati Indonesia, Bandung: Citra Aditya Bakti.

Emirzon, Joni, 2007, Hukum Usaha Jasa Penilai dari Perspektif Good Corporate Governance, Disertasi Universitas Diponogoro, Semarang.

Friedmann, W., 1990, Legal Theory,Stevens \& Sons Limited, London, 1960; Terjemahan: Muhammad Arifin, Teori dan Filsafat Hukum, Idelaisme Filosofis dan Problema Keadilan (Susunan II), Jakarta: Rajawali.

Fuady, Munir, 2010, Konsep Negara Demokrasi, Bandung: Refika Aditama.

Fuady, Munir, 2007, Sosiologi Hukum Kontemporer Interaksi Hukum, Kekuasaan, dan Masyarakat. Bandung: PT. Citra Aditya Bakti.

George, Robert P., 1996, The Outonomy of Law, Esssays on Legal Positivism, New York: Oxford University.

Greenawalt, Kent, 1996, Too Thin and Too Rich Distinguishing Features of Legal Positivism, dalam: Robert P. George, The Outonomy of Law, Esssays on Legal Positivism, New York: Oxford University.

Gunadi, Tom, 1995, Ekonomi Pancasila, Dalam kancah Pendapat Ekonomi. Bandung: Angkasa.

Haroso, 1997, Usaha Swasta dalam Sistem Ekonomi Pancasila; dalam: Mubyarto dkk (Editor), Ekonomi Pancasila, Yokyakarta: BPFE-Yokyakarta.

Hart, H.L.A., 2009, The Consept of Law, Clarendon Press-Oxford, New York,
1997; Penerjemah: M. Khozim, Konsep

Hukum. Bandung: Nusa Media.

Kartasapoetra, G., dkk, 1992, Hukum Perburuhan di Indonesia Berdasarkan Pancasila, Jakarta: Sinar Grafika.

Manan, Bagir, 2011, Kembali Ke Politik Pembangunan Hukum Nasional; Dalam: Elly Erawaty dkk, Beberapa Pemikiran Tentang Pembangunan Sistem Hukum Naional Indonesia, Bandung: Citra Aditya Bakti.

MD, Moh. Mahfud, 2000, Demokrasi Dan Konstitusi Di Indonesia, Studi Tentang Interaksi Politik Dan Kehidupan Ketatanegaraan, Jakarta: Rineka Cipta.

MD, Moh. Mahfud, 2010, Membangun Politik Hukum, Menegakkan Konstitusi, Jakarta: Rajawali Pers.

Pope, Jeremy, 1997, National Integrity System; Penerjemah: Iswira Laksana dkk, 1999, Pengembangan Sistem Integrasi Nasional, PTY. Jakarta: Pustaka Utama Grafiti.

Prasetyo, Teguh dan Abdul Halim Barkatullah, 2012, Filsafat, Teori dan Ilmu Hukum; Pemikiran menuju Masyarakat yang Berkeadilan dan Bermartabat, Kota Depok: PT. Raja Grafindo Persada.

Rasjidi, Lili, 1990, Dasar-Dasar Filsafat Hukum, Bandung: PT. Citra Aditya Bakti.

Rasjidi, Lili, 1993, Filsafat Hukum, Apakah Hukum itu; Bandung: PT. Remaja Rosdakarya.

Sastrapratedja, M., 2002, Kata Pengantar Etika Hukum; Dalam: E. Sumaryono, Etika Hukum, Relevansi Teori Hukum Kodrat Thomas Aquinas, Yokyakarta: Kanasius.

Sidharta, B. Arief, 2011, Sebuah Gagasan tentang Paradigma Ilmu Hukum Indonesia; dalam: Elly Erawaty dkk, Beberapa Pemikiran Tentang Pembangunan Sistem Hukum Naional Indonesia, Bandung: Citra Aditya Bakti.

Soejadi, 1999, Pancasila Sebagai Sumber Tertib Hukum Indonesia, Yokyakarta: Lukman Offset.

Sumaryono, E., Etika Hukum, Relevandi Teori 
Hukum Kodrat Thomas Aquinas, Yokyakarta: Kanasius,

Sunoto, 1985, Mengenal Filsafat Pancasila, Pendekatan Melalui : Etika Pancasila, Yokyakarta, PT. Hanindita.

Susanti, Ida, 2011, Merajud Nilai-Nilai Pancasila ke dalam Hukum Nasional tentangt Hubungan Industrial., Dalam: Elly Erawaty dkk, Beberapa Pemikiran Tentang Pembangunan Sistem Hukum Naional Indonesia, Bandung: Citra Aditya Bakti.

Susanto, Anthon F., 2010, Ilmu Hukum Non Sistematik, Yokyakarta: Genta Publishing.

Tukgali, Lieke Lianadevi, 2010, Fungsi Sosial Hak Atas Tanah, Jakarta: Gramedia.

Unger, Roberto Mangabeira, 1983, The Critical Legal Studies Movement, Cambridge University Press, London; Penerjemah: Narulita Yusron, 2012, Gerakan Studi Hukum Kritis, Bandung: Nusa Media.

Widjaya, Albert ,1988, Budaya Politik dan Pembangunan Ekonomi, Jakarta: LP3ES.

\section{Jurnal}

Iriantoro, Catur, "Kedudukan dan Relevansi Yurisprudensi untuk mengurangi Disparitas Putusan Perdata”, Majalah Varia Peradilan, No 312 November 2011.

Kusumaatmadja, Mochtar, "Pemantapan cita hukum dan Asas-asas Hukum Nasional di Masa kini dan Masa yang akan dating" dalam: Majalah Hukum Nasional No. 1, Tahun 1995, Jakarta, BPHN Departemen Kehakiman.

Syaifuddin, Muhammad, "Nasionalisasi Perusahaan Modal asing Ide Normatif Pengaturan Hukumnya Dalam UU NO. 25 Tahun 2007 Dan Relevansinya Dengan Konsep Negara Hukum Kesejahteraan Pancasila Dalam UUD 1945”, Jurnal Simbur Cahaya XVII (47) Fakultas Hukum Universitas Sriwijaya, Januari 2012.

Zanibar, Zen, Mei 2012, "Perizinan dan Ketenagakerjaan, Fenomena Otonomi Daerah Merespons Pasar Global", Jurnal Simbur Cahaya XVII (48), Fakultas Hukum Universitas Sriwijaya
Inderalaya.

Zhou, Yanfei, "A Convergence Analysis on the Efficiency of Public Job Placement Services in Japan", Japan Labor Review, 5 (1) Winter 2008. 